\title{
Representation of Ethnicity as Problem: Essence or Construction
}

\author{
by Joseph J. Pivato
}

"My Italian identity started to come out more and more. By the end of the summer I started to dream in Italian."

— Mary di Michele

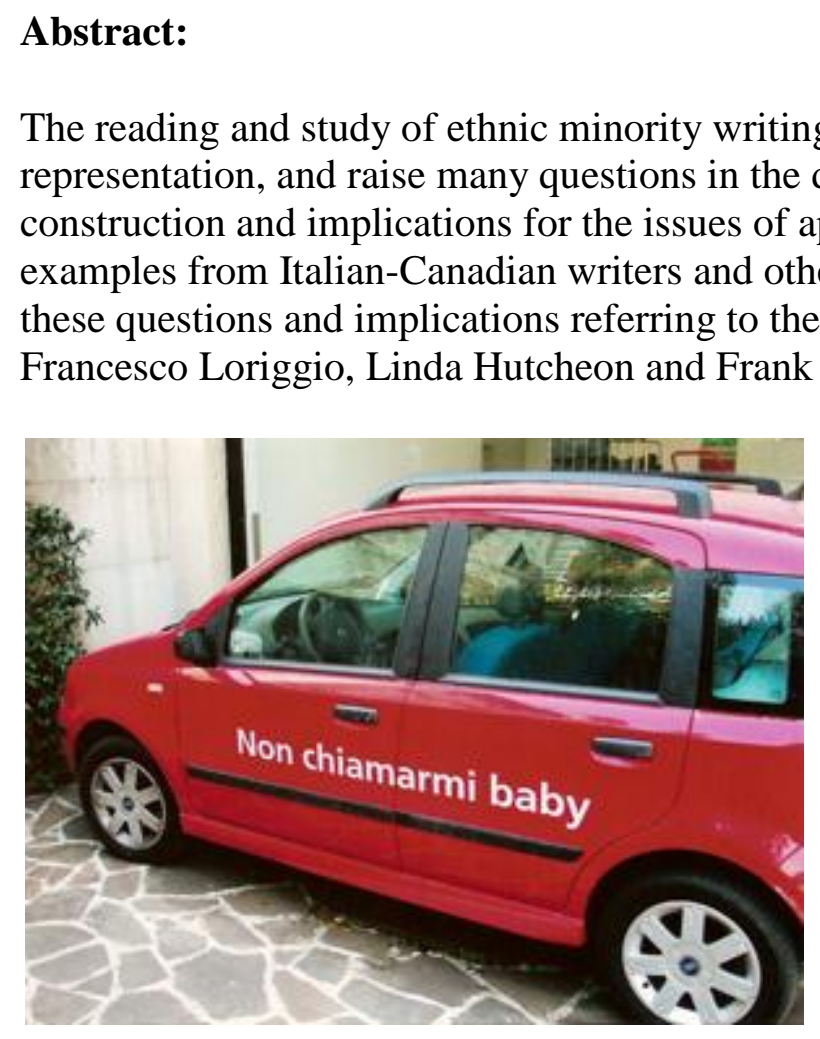

We begin with a scene from an Italian film, Padre Padrone, a scene which helps us to focus on some of the issues surrounding the question of representation. In Padre Padrone we see an Italy of the Third World, Sardinia, an island of shepherds, olive pickers and poverty. The final scene in the film has the author of the original story, Gavino Ledda, explain to the audience why after finishing his graduate degree in linguistics he did not take up a university position offered to him in Rome, but returned to the poverty of his small town to teach the peasant children. He explains that the university position gave him power over others, and implies that this power would have made him like his father-a padrone.

I was personally moved by this film because it recalled for me the poverty of the post-war Italy which I left behind in 1952. The film is set in the late sixties when the poverty of Sardinia is in sharp contrast to the economic miracle taking place in most of Western Europe. I was shocked 
by this final scene. Why, after trying to escape this poverty and oppressive family throughout the narrative, should Gavino decide to return to his town?

We have just witnessed the narrative of Gavino's brutal early life, and his final political choice clearly lends credibility to the representation of this story. The author speaks with the poor in his story, and not just about them from a distance. Gavino, though a university graduate, wants to identify with the powerless children of his village. This final scene highlights that the important relationships in the narrative are those of power and property. We witnessed the brutal murder of Gavino's cousin and have seen Gavino's father eagerly inherit his olive grove. Gavino chooses to try to change these power relations by returning and teaching the children to read. He gives them the education that he was denied by his own father. The film opens with the father pulling the young Gavino out of grade school in order to send him into the wasteland to mind the sheep. By escaping to Rome and taking up a position of power, Gavino indicates that he would have allowed his brutal father and those like him to win. He would have become like them. The brief final words by the adult Gavino Ledda tell us about the relationships of power and the representation of the subject. Gavino, the author, clearly gives us his position. Gavino is an example of what Gramsci called an organic intellectual, one who emerges from and continues to identify with an oppressed class.

\section{Authority and Authentic Voice}

My starting point for a discussion of the representation of ethnicity is a political position. Who is speaking and from what place? I think that in all my criticism of Italian-Canadian writing and other ethnic minority literature I have tried to be conscious of the position of the speaker. I have often focussed on the voice of the writer and his/her authority to speak about the minority experience. Nevertheless, I often get the impression that this idea of the authentic voice is dismissed by some of my colleagues as naive.

It is naive from the poststructuralism point of view which sees all differences as socially and historically constructed and not based on any fixed properties of nature. Any discussion of the authentic voice and the appropriation of voice becomes involved in the larger debate between essentialism and social constructionism which has animated feminist writers for over three decades (Fuss, 1989). This debate between essentialism and constructionism is also influencing the discourse on ethnic minority writing in Canada. We cannot avoid this question of biology, if only because blood relations are so important within many ethnic communities (Kostash,1993).

The research and study of ethnic minority writing is such a new area that it is necessary to use the author's signature as a marker of minority status. Names like Pier Giorgio Di Cicco, Nino Ricci, Mary di Michele, Marco Micone, Antonio D'Alfonso and Mary Melfi, all with those final Mediterranean vowels, were not the kinds of names normally found on Canadian literature courses and so they stood out immediately. Linda Hutcheon has pointed out that women with Italian family names who married non-Italians lost these name markers and the 'advantages' which went with them (1995).

As immigrants and the children of immigrants these authors were speaking for the first time about their communities and in many cases were the only speakers from these groups and so, 
willing or not, they have become the authority voices for these immigrant communities. Who decides that someone speaks for a particular group? We must assume that the groups consent to these writers speaking for them. Much like Gavino in the Sardinian film, these writers can speak with their community, and can do so in their own authentic dialects. They have not left their communities to speak about them from a distance and in a foreign language. When these writers use English or French to speak about their communities these languages come from the immediate experience of these people. At one point in the Canadian documentary film, Enigmatico, Antonio D'Alfonso complains that he is not happy with the quality of his writing. Though he can use English, French and Italian, he says he cannot master them as well as the native speakers of these standard tongues. This is exactly the point of authenticity. In his own body D'Alfonso reflects his community and its language problems. The people depicted in the writing of Frank Paci, Dino Minni, Mary di Michele, Caterina Edwards and others demonstrate that no matter how many university degrees these characters earn they do not escape the language or identity problems of their families.

Postcolonial theory and criticism have linked language and representation. In order to articulate, to represent the cultural difference of one's own group one must speak their language. Using English or another colonial language often involves translation, a problem we can only discuss briefly here (Pivato, 1987).

In her study of marginality Sneja Gunew cites Lacan's dictum that the unconscious is structured like a language, and she asks if that unconscious may be formed in relation to a particular language, rather than language in general (1994: 13). The quotation from Mary di Michele, which began this essay, is an example of this inscription of the original language in the body. During her first return trip to Italy and to the town of her birth Mary di Michele began to dream in Italian once more, as she must have done as a little girl. Geography is another element in the problem of representation. As Canadians we have become notorious for our obsession with landscape.

Whether the immigrant writer uses the language of the old country or that of the new he/she is involved in translation. The representation of cultural difference through the old language in the new country may produce the deterritorialisation of the dominant language (Deleuze, Guattari), but it also changes the minority language in terms of context, meaning and even sound. How can it authentically represent the minority experience if it is itself changing in the new territory? The Italian of Maria Ardizzi's four Canadian novels is not the same language as that of Italy, because this process of deterritorialisation influences it. Ardizzi is translating while writing in standard Italian. Her heroine, Nora Moratti is a Canadian character who speaks Italian.

The use of the new language, like English or French, in the new country by the immigrant writer or his/her children presents other problems of translation. Representing the immigrant experience, which was originally, felt in Italian, or in Japanese, or in Bengali, into English changes the experience. The ethnic minority writer is involved in the process of translation, in the search for the authentic presentation of the experience. With Joy Kogawa the use of the Japanese culture also involves the use of silence, an element that is difficult to translate into another language, and especially a dominant language like English, which has no silences. On 
the other hand, Hiromi Goto uses whole Japanese sentences to capture the untranslatable in Chorus of Mushrooms:

What do you mean? Eigo hitotsu mo hanashitenal to omou kedo. Haven't we been talking Japanese all along? (197)

In Goto's narrative there are some Japanese characters and many Japanese terms, which are written phonetically in the Roman alphabet and so have already undergone one transformation.

\section{Appropriation of Voice}

Translation and the appropriation of voice are two activities, which are linked. All forms of translation have been practiced for centuries out of a variety of needs. Translation assumes that a given author or text cannot speak for themselves and need someone to interpret them into another language. Appropriation of voice, on the other hand, appears to be a recent activity, which has all kinds of undesirable political dimensions. Given the many problems involved in translation and the search for the appropriate expression of the minority experience we can understand the gravity of the problem of appropriation of voice. It is an activity, which seems to assume that the minority person cannot speak for himself/herself, when in fact they can, and should be given every opportunity to do so. When a person from outside the minority group assumes to speak about the experience of, and for the people of the marginalized group it is not just a political problem but an aesthetic one as well. It cannot be explained away by appealing to the freedom of the imagination of the artist. When power is involved there is no real freedom of the imagination for the artist. Appropriation of voice, by definition is not a dialogue among equals, but an exercise of power by the appropriator over the minority object, who is thus made an object and not a subject.

While I am well aware of the dangers of biological essentialism, I am equally sensitive to the power relations in the major languages and literatures, which also belong to and were used as instruments by colonial powers. It would be absurd to maintain absolutely that only people of Italian blood could write about Italians. This would eliminate half the plays in Shakespeare's canon. But when we look closely at this example of Shakespeare we see that the power relations do not put Italy at a disadvantage. The powerful city-states of Italy were leaders of the Renaissance and the English playwright was simply imitating what was considered the most fashionable and popular culture of his time. Shakespeare was not appropriating the voices of Italians since their artists, writers and musicians were speaking for themselves very loudly all over Europe. There was no unequal power relationship between the languages and cultures of England and Italy at the time.

If we look at a more recent example of borrowing from another culture we may find that the power relations are very unequal. The case is that of W. P. Kinsella and his short stories about a Native community in Alberta. While the stories are fiction and the characters are all imaginary, the location of the reserve is similar to that of a real reserve near Hobbema, Alberta. The fact that the stories are humorous and depict these Native people in comical situations can be seen as degrading, and maintaining the negative stereotypes of Native people as not very intelligent. As an Italian I can appreciate the situation of seeing your own people depicted as either foolish 
clowns or as evil. But the problem of appropriation here depends on the disparity in the power relations of the two. Kinsella is a successful published writer with a North American audience, who has turned his books into popular movies and who has access to all the media and the most powerful publishers. And he has taken advantage of all these forms of communication to denounce his critics and accusers as 'the thought police.' The Native people of Hobbema have few avenues of self-expression about this issue or any other. Their poor economic position gives them no ability to exercise their agency and to contest the representation of negative stereotypes. The very fact that the cause against appropriation in this case was taken up by other white writers and academics in Canada rather than by the Natives of the community would supports this view of their position of powerlessness. And sadly it also reveals the paternalistic position in which this particular group of Native people still find themselves. Even their white advocates are guilty of speaking for them. Happily many native writers are beginning to speak for their own communities and to their Native readers. A Tomson Highway or a Drew Hayden Taylor can now critique their own Native problems.

In Rudy Wiebe's books, which depict Native people, we see an historical encounter between the dominant white world and that of the Natives. In Discovery of Strangers Wiebe tries to place the two cultures on more or less equal ground. But can he too be accused of appropriation of voice when he puts English words into the mouths of these long dead Native figures? For AfricanCanadian writer Marlene Nourbese Philip the answer to this question is yes:

For the white artist/writer/painter/musician — particularly the male of the species—the world is his oyster, and if he wishes to use Asian, African or Native culture in his work, then why the hell not? What does white mean, if it does not mean being able to lay waste and lay claim to anything you may happen to set your mind to? That is the moral turpitude at the heart of white "civilization." (1992:219)

In his important book, Orientalism, Edward Said has some cogent observations about the problems of representation, which can be applied to the European depiction of Native people in the Americas and later visible minorities. For Said the way in which the West constructed the Orient was mediated by a whole set of political, ideological, ethnocentric, religious and cultural forces. (203) In addition to the violence of Western imperialism in the Orient there was the violence of the representation itself, the power to select, to exclude material, to translate and interpret in terms of modern Europe and all from positions and perspectives, which were not visible to readers. (121, 207-9). Elsewhere Said has observed that this violence is also due to the contrast between the act of representation and the calm exterior of the image, the text. (1990: 95) We must also be sensitive to the fact that even the marginal, ethnic minority author is often in a dominant position in comparison to the subject.

The writer who studies other cultures cannot avoid trying to "master" them through the power of expertise. Does this acquired knowledge also give the writer the ability to speak for the marginal group, and thus appropriate their voice? Or is the writer an interpreter, a translator of the words for the minority people who may have another language? Does this privilege of speaking with them also require the writer to live with them, in the same location? Only from this position can the writer understand the differences between the Western Tradition and the local culture. The 
writer who speaks with the minority group, whether it is his own or from another culture, recognizes the power relations and the agency of the other. (See Fine, 1994)

Contemporary theories have made us aware that even narratives of minority experience are susceptible to all the contradictions inherent in texuality. Even innocent biographical narratives come to us textualized as representations, which may have done violence to the original events (Buss). No language is neutral. What is important is the position and power of those being depicted in the literary work. As Said observes:

What we must eliminate are systems of representation that carry with them the kind of authority which...has been repressive because it doesn't permit or make room for interventions on the part of those being represented. (Said, 1990:95)

Many ethnic minority writers themselves articulate their own difficulty with the power relations in representation. Frank Paci acknowledged the literacy problems in his own immigrant family, their lack of access to his English language works, and wondered if film might give them the opportunity to participate in the discourse. (Unpublished correspondence, 3 March, 1981)

Representation and appropriation of voice is a difficulty for all writers. Sneja Gunew points out that we use the term representation in at least two senses: the depiction of a subject, and as delegation, when someone speaks for a group or individual. (1994: 31) Writers and critics who are delegates for marginal or minority groups may find themselves in the situation of Gavino Ledda. From their position of power in the hegemony of Western Civilization, how do they really speak for a powerless group? In using the language of the dominant culture and the discourse of sophisticated theory can they still address the concerns of the marginal community? With every university degree there comes a level of separation between the writer and his/her community. And so we can see that the only concrete links this person may have with these original roots is to try to speak with and for these people. These tasks are not unproblematic (Paci, 1985: 47).

The case of the Italian-American writer and critic Frank Lentricchia illustrates the ambivalent feelings produced by academic training on the one hand and ethnicity on the other. In his two books on novelist, Don DeLillo, Lentricchia praises him for his ability to escape their Italian ethnicity (1991:2). But in two other publications, especially his autobiographical, The Edge of Night, Lentricchia obsessively reviews the meaning of his Italian background. In an interview he confesses:

But when I write, I'm aware, at some level - not always but intermittently - that I'm writing from a position as a critic who is not in a typical position in the American academy. That fact sometimes weighs heavily upon me. I can't say that it's shaped all of my work: if you read some of my early stuff, you'll see no relationship with my Italian-American working-class background. But, these days, I have to say that one of the things I'm aware of is that I'm not a gentleman scholar. And, especially in my last two books, this has made me wary of theories of literature that avoid the kinds of differences you can't avoid. (1987: 182) 
The delegated critic who tries to speak about, and for minority groups often finds that he/she must point to the norms of universality assumed by white western societies. These norms are so taken for granted as to be invisible to us. How can we understand the difference between the dominant cultures and the subordinate ones? Will the theories of European deconstruction help us here? In his work Said is critical of the separation between literary culture and social problems:

This has given rise to a cult of professional expertise whose effect in general is pernicious. For the intellectual class, expertise has usually been a service rendered, and sold, to the central authority of society. This is the trahison des clercs of which Julien Benda spoke in the 1920s. (1983: 2)

The problem of representing alterity is bound up with the questions of position and of power. Psychologist Michelle Fine advises researchers to "work the hyphen" in order to probe these power relations (1994).

\section{Representation and the Conventions of Realism}

In the not too distant past ethnic minority writing was dismissed as work of low literary value because it was perceived as too sociological. The novels of Italian-American writers such as Pietro di Donato and John Fante were criticized as poor realism or naturalism. In general ethnic minority writing was reduced to the oral history of immigrants or to the sociology of new settlement in ethnic neighbourhoods. I have always taken this dismissive criticism and turned it around. It is precisely because of this attention to the realistic representation of the immigrant story that the works of a Frank Paci, or an M. G. Vassanji are valuable both as literature and as story. As I have argued elsewhere writers like Maria Ardizzi and Joy Kogawa strike a responsive cord in readers because they are reconstructing a history of immigrant women, which has been lost and neglected. To me this biographical dimension increases the literary value of their work, rather than diminishing it.

In recent years the works of ethnic minority writers have been criticized in the context of contemporary theory. These works are often seen as stuck in the conventions of literary realism and as not experimental in their exploration of new forms of representing the subject. Some critics have tried to read these works as postmodern. And we can see how it is appealing to read many ethnic minority novels as open to postmodern theories, which promote the "decentred subject," support the fragmentation of linear narratives and show scepticism about master narratives.

I have argued that many ethnic minority writers do not want to decentre the subject but simply to find, or construct the minority subject for the first time. They do not use anti-narrative fragmentation because they are often trying to reconstruct a lost narrative for the first time from the chaos of fragmented oral histories (Pivato, 1996).

Critical theory not only questions the intentions of the minority writer, but also the need to recognize the very existence of the author. Much contemporary criticism tries to avoid the role of the author by preferring the term "text" rather than "work," which implies the creation of an 
author. For Foucault and his followers the author is merely an "author function" in the discursive analysis of art. It has become a troubling issue that just at the point when minority writers find individual voices and assert their existence, postmodern theory seems to deny the need for this existence. In response to this obliteration of identity Francesco Loriggio has pointed out that the signature of the marginalized writer is an important marker:

The most idiosyncratic and most conspicuous feature of ethnic texts is also their most controversial one. It has to do with the function of the author. (1987: 55 )

The recognition of the individual author is linked to the identity of the minority group and to their history. It is a history consisting, not of momentous world events from history books, but of little stories, family chronicles, tales of displaced people, autobiographies of women and men. The discourse of feminist writers on the issues of essentialism and the body, and especially those studying life writing, has helped us to re-evaluate the work of ethnic minority writers as literary works, as texts which reward reading, study and research. (Neuman, 1991, 1993, Kadar, 1992, Verduyn, 1995)

The conventions of literary realism are the ones, which lend themselves most easily to the story telling of ethnic minority groups. Conventional narrative permits the minority writer to tell the story in the most direct manner and to develop characters who exercise some form of agency. It is this agency, which allows writers to critique the social values of both the old and the new country. It is this agency which allows people the freedom to act in conformance with, in opposition to, or without regard for biological or social determinants. (Rychlak, 50).

\section{Agency}

Along with the preference for the conventions of literary realism often found in ethnic minority writing is the common use of the first person narrative. The examples are numerous: Frank Paci's novel, Black Blood, Hiromi Goto's Chorus of Mushrooms, Gerard Etienne's Le negre crucifié, and in Australia Rosa Cappiello's Paese fortunato. One of the attractive aspects of speaking in the first person, in one's own voice, is that it gives the illusion of power and control over one's life; a sense of self-determination that never existed in the real experience of dislocation. In a sense the agency of the main character in the narrative parallels that of the author with the freedom to tell his own or her own story.

In the past critical theory was able to accommodate the intention and authority of the writer, but this has changed. Current literary theories proclaim the death of the author (Barthes). Readerresponse theory privileges the interaction of the reader with the text. Umberto Eco claims that the author is only a strategy of the text and that the real text is a product of the reader's consciousness. Wolfgang Iser agrees and maintains that the text only exists through the activity of the reader. We can see the gap here between the sophisticated urban culture of Europe with its self-reflexive theories, which are meant to honestly do away with the cult of personality, and the basic activities of the minority writer who is trying to articulate an experience, develop an identity and find a space in society. 
In ethnic minority writing we have not only the recuperation of the author, but also the exercise of his or her authority as a voice in the, and for the community. This recognition of the authority of the author is one response to the appropriation of voice from outside the community. When we write about ethnic minority authors we are implicitly recognizing their vital role as voices in their communities. In her study of Dionne Brand's poetry Himani Bannerji focuses on this important dimension in her writing:

Dionne Brand, born in Trinidad, in Guaguyare (1953), immigrant to Canada, woman and black is another such poet. To read her poetry is to read not only about her but also about her people. Her identification with their struggles both in the metropole of Canada and in the hinterland of the Caribbean. (24)

In her study of Marco Micone's French plays in Quebec Sherry Simon directly articulates his role in the title itself, "The Voice of Authority." The French plays not only provide Micone with a clear access to the political discourse of Quebec but also give him a voice for the Italo-Quebecois community, a voice it did not previously have. These Gens du silence are never going to be silent again.

For Dionne Brand, Marco Micone, and Hiromi Goto the putting into print of words from the ethnic community is an exercise in the agency of these people. It is in this way that they can freely question both the biological and the social determinants they confront everyday. Linda Hutcheon, despite her attachments to postmodernism, recognizes the value of intentionality in the writer and the reader when it comes to literatures of resistance. In her reinterpretation of the theory of irony she writes:

After all, the touchy political issues that arise around irony's usage and interpretation... invariably focus on the issue of intention (of either ironist or interpreter). And it is because of its very foregrounding of the politics of human agency in this way that irony has become an important strategy of oppositional rhetoric. (1994: 11-12)

The representation of ethnic difference in literature takes many forms, which combine both the biology of blood relations and social construction. Implicit in the idea of difference is the freedom to resist these factors. Helped by the example of half-forgotten immigrants, we as writers and critics should constantly be engaged in questioning the categories of ethnicity, race and gender.

We will end with an image from another film. This one is from the historical Italo-Quebecois film, La Sarrasine, by Paul Tana and Bruno Ramirez. Italian immigrant, Giuseppe Moschella is arrested and imprisoned for an accidental death. He orders his wife, Ninetta, to return to Italy, but she refuses and instead stays in Canada to plead his case. She resists the bullying of Giuseppe's older brother and remains in Canada even after Giuseppe takes his own life in despair. In contrast to her husband who gave up Ninetta is a paradigm of agency in a weak marginalized figure. As a powerless immigrant woman in turn-of-the-century Quebec Ninetta's resistance is of three kinds: first, she wants to fight the legal system in order to get justice for her husband, second, she wants to decide for herself where she is going to live, and third, she wants to tell her own story in her own words, which in this case are Sicilian. The film ends with an 
image that is a combination of Canadian and Italian elements: the black clad Ninetta standing in a field of snow gazing out at the horizon. It is by representing herself as visible that Ninetta can become a part of the new landscape.

(C) 1996 Joseph Pivato see Journal of Canadian Studies 31:3, 1996.

\section{Works Cited}

Ashcroft, Bill et al.. The Empire Writes Back. London: Routledge, 1989.

Bannerji, Himani. The Writing on the Wall: Essays on Culture and Politics. Toronto: TSAR, 1993.

Barthes, Roland. "The Death of the Author." Modern Criticism and Theory. Ed. D. Lodge. New York: Longman, 1988.

Blodgett, E.D.. "Towards an Ethnic Style." Canadian Review of Comparative Literature 22:3-4 (1995): 623-638.

Brand, Dionne. Bread out of Stone: Recollections sex, recognitions race, dreaming politics. Toronto: Coach House Press, 1994.

Buss, Helen M.. "Canadian women's autobiography: some critical directions." A Mazing Space. Eds. S. Neuman \& S. Kamboureli. Edmonton: Longspoon / NeWest Press, 1986.

Clarke, George Elliott. "Must all Blackness be American?" Canadian Ethnic Studies 28:3 (1996).

Deleuze, Gilles \& F. Guattari. Kafka: Towards a Minor Literature. Minneapolis: University of Minnesota Press, 1986.

Etienne, Gerard. Le Negre crucifié. Montreal: Editions Balzac, 1994.

Fee, Margery. "What Use Is Ethnicity to Aboriginal Peoples in Canada?" Canadian Review of Comparative Literature 22: 3-4 (1995): 683-691.

Fine, Michelle. "Working the Hyphens: Reinventing Self and Other in Qualitative Research." Eds. N.K. Denizen \& Y.S. Loncoln. Handbook of Qualitative Research. Thousand Oaks: Sage Publications, 1994.

Fuss, Diana. Essentially Speaking: Feminism, Nature \& Difference. New York: Routledge, 1989.

Goto, Hiromi. Chorus of Mushrooms. Edmonton: NeWest Press, 1994.

Gunew, Sneja. Framing Marginality: Multicultural literary studies. Melbourne: Melbourne University Press, 1994. 
Hutcheon, Linda. Irony's Edge: The theory and politics of irony. New York: Routledge, 1994. . "Crypto-Ethnicity." MLA Conference paper, 1995.

Kadar, Marlene Ed.. Essays on Life Writing: From Genre to Critical Practice. Toronto: University of Toronto Press, 1992.

Kinsella, W.P. The Moccasin Telegraph and other stories. Markham: Penguin Books. 1983.

Kostash, Myrna. Bloodlines: A Journey into Eastern Europe. Vancouver: Douglas \& McIntyre, 1993.

Lentricchia, Frank. The Edge of Night. New York: Random House, 1994.

. Ed.. Introducing Don DeLillo. Durham: Duke University Press, 1991.

. Interview in Imre Salusinszky Criticism in Society. New York: Methuen, 1987.

Loriggio, Francesco. "The Question of the Corpus: Ethnicity and Canadian Literature." Future Indicative, Ed. J. Moss. Ottawa: University of Ottawa Press. 1987.

Micone, Marco. Gens du silence. Montreal: Quebec/Amerique, 1982.

Neuman, Shirley \& G. Stephenson, Eds.. ReImagining Women: Representation of Women in Culture. Toronto: University of Toronto Press. 1993.

, Ed. Autobiography and Questions of Gender. London: Frank Cass, 1991.

Paci, F.G. "Tasks of the Canadian Novelist Writing on Immigrant Themes." Contrasts: Comparative Essays on Italian-Canadian Writing. J. Pivato, Ed. Montreal: Guernica Editions, 1985.

Philip, Marlene Nourbese. Frontiers: Essays and Writings on Racism and Culture. Stratford: Mercury Press, 1992.

Pivato, Joseph. "Shirt of the Happy Man: Theory and Politics of Ethnic Minority Writing." Canadian Ethnic Studies 28:3 (1996).

. "Constantly Translating: The Challenge for Italian-Canadian Writers." Canadian Review of Comparative Literature XIV.1 (1987).

Ramirez, Bruno \& Paul Tana. La Sarrasine. Montreal: Boreal, 1992. (Scenario)

Rychlak, Joseph F. "Morality in a Mediating Mechanism? A Logical Learning Theorist Looks at Social Constructionism." Social Discourse and Moral Judgment. Ed. D. N. Robinson. San Diego: Academic Press, 1992. 
Said, Edward Orientalism. New York: Random House. 1978.

. The World, the Text and the Critic. Cambridge: Harvard University Press, 1983.

"In the Shadow of the West." Discourses: Conversations in Postmodern Art and Culture.

Eds. R. Ferguson et al. Cambridge: MIT Press, 1990.

Simon, Sherry. "Speaking with Authority: The Theatre of Marco Micone." Canadian Literature 106 (1985).

Smith, Paul. Discerning the Subject. Minneapolis: University of Minnesota Press, 1988.

Taylor, Drew Hayden. "Pretty Like a White Boy: The Adventures of a Blue Eyed Ojibway." This Magazine (August 1991).

Verdicchio, Pasquale. "Bound by Distance: Italina-Canadian Writing as Decontextualized Subaltern." VIA: Voices in Italian Americana 3.2 (1992).

Verduyn, Christl. Lifelines: Marian Engel's Writings. Montreal: McGill-Queen's University Press, 1995. 